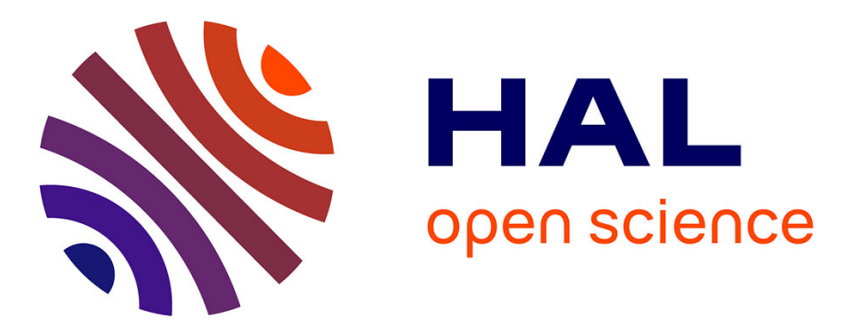

\title{
Physical-chemical characterization of sludge and granular materials from a vertical flow constructed wetland for municipal wastewater treatment.
}

\author{
B. Kim, M. Gautier, P. Michel, R. Gourdon
}

\section{- To cite this version:}

B. Kim, M. Gautier, P. Michel, R. Gourdon. Physical-chemical characterization of sludge and granular materials from a vertical flow constructed wetland for municipal wastewater treatment.. Water Science and Technology, 2013, 68 (10), pp.2257-63. 10.2166/wst.2013.485 . hal-00955473

\section{HAL Id: hal-00955473 \\ https://hal.science/hal-00955473}

Submitted on 4 Mar 2014

HAL is a multi-disciplinary open access archive for the deposit and dissemination of scientific research documents, whether they are published or not. The documents may come from teaching and research institutions in France or abroad, or from public or private research centers.
L'archive ouverte pluridisciplinaire HAL, est destinée au dépôt et à la diffusion de documents scientifiques de niveau recherche, publiés ou non, émanant des établissements d'enseignement et de recherche français ou étrangers, des laboratoires publics ou privés. 


\title{
Physical-chemical characterization of sludge and granular materials from a vertical flow constructed wetland for municipal wastewater treatment
}

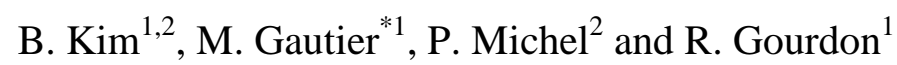

${ }^{1}$ University of Lyon, INSA of Lyon, LGCIE, 20 av. A. Einstein, F-69621 Villeurbanne cedex, France

${ }^{2}$ SCIRPE, Society of design and production engineering for wastewater purification, 5 Allée Alban Vistel, F-69110 Sainte-Foy-Lès-Lyon, France

*mathieu.gautier@insa-lyon.fr

\begin{abstract}
:
The use of Vertical Flow Constructed Wetlands (VFCW) is well developed in France and other countries for the treatment of wastewaters from small communities. The patented Azoé ${ }^{\circledR}$ process has been developed by a French company SCIRPE in order to improve denitrification and phosphorus removal as compared to classical VFCWs. It includes a biological trickling filter pretreatment followed by two stages of partially flooded VFCW (pf-VFCW).

The performances of partially flooded VFCW are well demonstrated for the removal of organic matter and nitrogen. The system is now being considered for phosphorus removal as well. In this article, sludge and granular materials sampled from the filters of a municipal plant where Azoé ${ }^{\circledR}$ system has been operated for 8 years were analyzed in order to provide data that may contribute to better understand the dynamics of phosphorus retention.

Elemental analyses showed that phosphorus was predominantly captured in the sludge layer accumulated at the surface of the first stage. The progressive mineralization of the sludge over time was also clearly highlighted. The phosphate phases were mainly associated with iron and calcium. The transport of phosphorus via the migration of fine particles through the porous medium in the first stage was also observed.
\end{abstract}

Keywords: extensive wastewater treatment, vertical flow constructed wetland, phosphorus, leaching, sludge, solid phase analysis. 


\section{Introduction}

The use of Vertical-Flow Constructed Wetlands (VFCW) for the treatment of wastewater from small communities has been growing very significantly since 1990s in France (Molle et al., 2005). VFCWs have demonstrated their efficiency in treating the organic load from domestic wastewater and their relatively good performances for nitrification (Hammer, 1989; Kadlec et al., 2000). However, there are still questioned about their capacity to remove nitrogen by nitrification / denitrification and to retain phosphorus (Brix et al., 2001; Kadlec and Wallace, 2009). Indeed, the release of nitrates and phosphorus into sensitive aquatic ecosystems may promote eutrophication, and therefore the concentration in the treated effluents must satisfy increasingly low regulatory limits.

The french company SCIRPE has developed a compact VFCW process called Azoé ${ }^{\circledR}$ (patents EP1857419A1 - Michel, 2007; PCT/EP2012/058119 - Michel, 2012) which includes: (1) a biological aerobic trickling filter as a pre-treatment stage of the organic load, (2) ferric chloride $\left(\mathrm{FeCl}_{3}\right)$ addition for phosphorus removal and (3) two stages of partially flooded vertical-flow constructed wetlands (pf-VFCW) for nitrogen removal.

Whereas nitrogen is traditionally released in the form of gaseous $\mathrm{N}_{2}$ through nitrification / denitrification, this is not possible for phosphorus. Regarding phosphorus removal, physico-chemical processes are usually used as post-treatments in constructed wetland systems. The use of specific materials with high phosphorus retention capacity is a solution proposed in some subsurface flow constructed wetland systems (Vohla et al., 2011). In the Azoé ${ }^{\circledR}$ process, phosphorus is precipitated by injection of $\mathrm{FeCl}_{3}$ at the output of the trickling filter and the phosphate precipitates thus formed are retained by filtration through the pfVFCWs. Suspended solids thereby progressively accumulate as a sludge layer on the surface of pf-VFCWs, which is removed by dredging every 10 to 15 years.

The efficiency of phosphorus removal from wastewater by ferric chloride addition was clearly highlighted (El Samrani et al., 2004, 2008; Caravelli et al., 2010; De Gregorio et al. 2011), but the forms of phosphorus in the sludge and its fate in the long term are not known. Despite numerous studies (Golterman, 2001; Smith et al., 2008; Szabó et al., 2008), phosphorus chemistry and its reactions in the environment are still not clearly known. Kim et al. (2012) recently reported a $24 \mathrm{~h}$ flow proportional sample monitoring of the Azoé ${ }^{\circledR}$ process revealing that phosphorus was mainly retained in the sludge accumulating at the surface of the first pf-VFCW stage. The surface sludge layer therefore constitutes a stock of phosphorus which may be released under the influence of external factors such as $\mathrm{pH}$ and Eh.

In order to contribute to the estimation of the possible risk of phosphorus release, the present study focused on the characterization of the sludge and other of granular materials sampled from a wastewater treatment plant using the Azoe ${ }^{\circledR}$ process. The goal was to identify more precisely the distribution of phosphorus in the analyzed samples, since the speciation of phosphorus will govern its potential release into solution depending on the physical chemical conditions.

\section{Materials and Methods}

$\underline{\text { Site of investigation }}$

The first Azoé ${ }^{\circledR}$ plant, in operation since 2004 in Vercia (Jura, France), was selected for field monitoring. Figure 1 shows a simplified diagram of the plant. This plant treats mostly 
domestic wastewater, but also receives wine-production effluent in autumn. Its maximum capacity is 1,100 Population Equivalent (PE).

The Azoé ${ }^{\circledR}$ system includes a screening operation of the raw wastewater influent and two pumping stations (Figure 1). The first pumping station (PS1) is used to feed the trickling filter and the first stage of wetland (pf-VFCW1) and the second one (PS2) is used to feed the second stage of wetland (pf-VFCW2). The role of the trickling filter is to degrade the most readily biodegradable fraction of the organic load and thereby diminish the required surface of wetland down to a maximum of $1.5 \mathrm{~m}^{2}$ per Population-Equivalent (PE) as compared to $2 \mathrm{~m}^{2}$ for classical two-stage VFCWs (Molle et al., 2005). In addition, the trickling filter contributes significantly to the nitrification process.

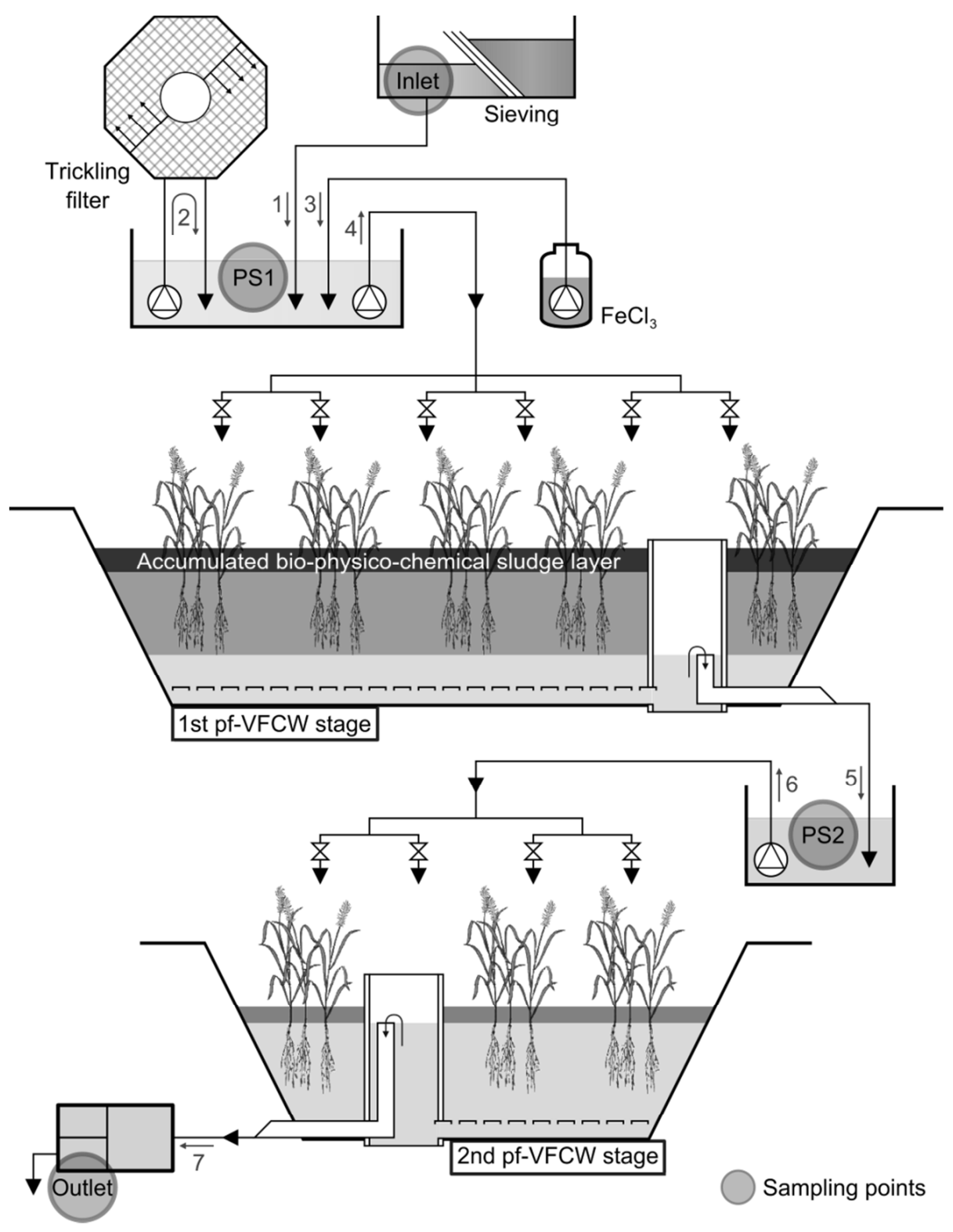

[Figure 1] Simplified diagram of Vercia wastewater treatment plant: numbers indicate chronological order of treatment sequence.

The treatment achievement takes place in the two stages of pf-VFCWs (Kim et al., 2012). Each filtration stage consists of two different zones: the upper zone which is not flooded, and 
the lower one which is flooded. These conditions allow a good efficiency in nitrogen removal through sequential nitrification / denitrification. The depth of the flooded zone can be adjusted to optimize efficiency.

The depth of filter materials in the pf-VFCW is $0.8 \mathrm{~m}$. The filtration layer is made of one layer of fine gravels in the first stage (particle size 2-5 mm) and one layer of sand in the second stage (particle size $0-4 \mathrm{~mm}$ ). The level of water is adjustable via a syphon in the drainage collect station. The total surface of each pf-VFCW stage is $600 \mathrm{~m}^{2}$. The first stage is divided into three hydraulically independent identical units of $200 \mathrm{~m}^{2}$, which are alternately fed. Their bottom drainage systems communicate one with each other. The second stage is completely separated into two identical units of $300 \mathrm{~m}^{2}$ which are fed alternately to favour mineralization of sludge. Each unit is fed over a period of 7 days and then rested for 14 days (for the first stage) or 7 days (for the second stage).

The average depth of sludge layer accumulated on the first stage of pf-VFCW since its implantation was around $16 \mathrm{~cm}$, corresponding to a rate of accumulation of about $2 \mathrm{~cm}$ per year. The fine particles of the sludge may possibly migrate downward during the operation of the treatment. The extent of this phenomenon depends on the porosity of the filter medium and hydraulic conditions. At the same time, the sludge may undergo various bio-physicochemical changes depending on the environmental conditions ( $\mathrm{pH}, \mathrm{Eh} /$ aeration, humidity, etc.).

\section{$\underline{\text { Sampling and preparation of the samples }}$}

Samples of several types of materials were taken from Vercia wastewater treatment plant:

- Samples of suspended Solids (SS) were taken from the first pumping station (PS1, see Figure 1). This material is mostly made of microbial biomass from the trickling filter and precipitates from the stage of $\mathrm{FeCl}_{3}$ addition.

- Sludge material was taken from the surface of first pf-VFCW stage.

- Gravel material was taken below the sludge layer of the first pf-VFCW stage.

- Sand material was taken from the second pf-VFCW stage.

Sludge sampling was done by manual shovelling of the sludge layer. SS from PS1 were collected by wet sieving at $45 \mu \mathrm{m}$ of the suspension resulting from the injection of ferric chloride into the effluent from the trickling filter. All materials were transported to the laboratory immediately after sampling and stored at $4{ }^{\circ} \mathrm{C}$ for a maximum of 2 days until they were freeze-dried, finely grinded and then analyzed.

\section{$\underline{\text { Analytical methods }}$}

Organic Matter $(\mathrm{OM})$ contents of dried samples were estimated by calcination at a temperature of $550{ }^{\circ} \mathrm{C}$ for at least $1 \mathrm{~h}$. Elemental analysis was performed by alkaline fusion $\left(\mathrm{LiBO}_{2}\right)$ followed by acid digestion and subsequent analyses of the solutions using inductively coupled plasma atomic emission spectrometry (ICP-AES). The following 10 major elements were determined: silicon $(\mathrm{Si})$, aluminium $(\mathrm{Al})$, iron $(\mathrm{Fe})$, manganese $(\mathrm{Mn})$, magnesium $(\mathrm{Mg})$, calcium $(\mathrm{Ca})$, sodium $(\mathrm{Na})$, potassium $(\mathrm{K})$, titanium $(\mathrm{Ti})$ and phosphorus $(\mathrm{P})$.

Mineralogical characterization was carried out on dried and calcinated samples using X-ray diffraction (XRD) performed with a BRUKER ${ }^{\circledR}$ D8 Advance instrument equipped with a 
copper anticathode. The diffractograms were interpreted using EVA software for phase identification. Experimental measurement parameters were $4 \mathrm{~s}$ counting time per $0.02^{\circ} 2 \theta$ step.

Fourier Transform Infrared (FTIR) spectrometry was also performed on same samples using a Perkin-Elmer Spectrum One FTIR spectrometer. The samples were dispersed in $\mathrm{KBr}$ powder ( $5 \mathrm{mg}$ of sample in $300 \mathrm{mg}$ of $\mathrm{KBr}$ ). The operating conditions were 10 scans and $1 \mathrm{~cm}^{-1}$ resolution. The studied wavenumber range was $450-4.000 \mathrm{~cm}^{-1}$.

\section{Results and discussion}

\section{$\underline{\text { Global parameters }}$}

Contents in Organic Matters (OM) and Mineral Matters (MM) are shown in Figure 2. The OM content was lower in the sludge than in suspended solid (SS), indicating that the mineralization process of OM at the surface of the first pf-VFCW stage was efficient. Due to the mineralization process, the mineral phase of SS was concentrated in the sludge as confirmed by the elemental compositions of the samples (Table 1).

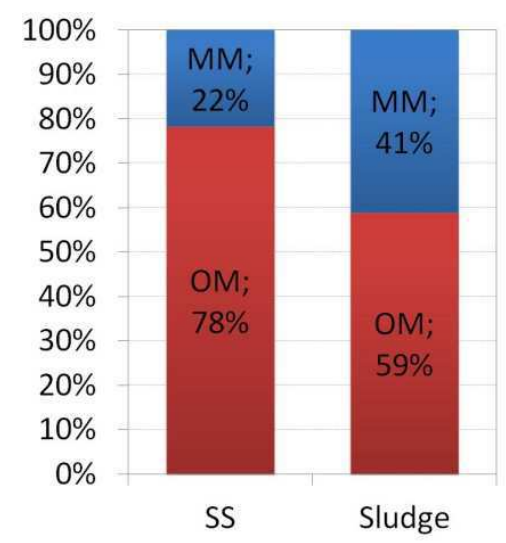

[Figure 2] Organic matter (OM) and mineral matter (MM) contents in sludge and suspended solids (SS).

Table 1 shows the total elemental content of the analyzed samples. All major elements except $\mathrm{Na}$ were found at a higher concentration in the sludge as compared to the SS. This can be explained by the higher content of OM in SS sample (Figure 2). Phosphorus contents were found to be $14.0 \mathrm{~g} \mathrm{~kg}^{-1}$ in SS and $19.4 \mathrm{~g} \mathrm{~kg}^{-1}$ for sludge, highlighting the retention of $\mathrm{P}$ at the surface of the first pf-VFCW stage. 
[Table 1] Elemental content in the suspended solid (SS) and sludge samples

\begin{tabular}{|c|c|c|c|c|}
\hline & \multicolumn{4}{|c|}{ Total elemental content ( $\mathrm{g} \mathrm{kg}^{-1}$ dry sample) } \\
\hline & $\begin{array}{l}\text { Suspended Solid } \\
\text { (SS) }\end{array}$ & Sludge & Gravel layer & Sand layer \\
\hline $\mathbf{S i}$ & 11.1 & 72.1 & 276.3 & 368.2 \\
\hline Al & 3.0 & 23.4 & 17.3 & 54.8 \\
\hline $\mathbf{F e}$ & 17.2 & 22.9 & 13.8 & 9.8 \\
\hline Mn & 0.1 & 0.2 & 0.1 & 0.3 \\
\hline Mg & 2.0 & 3.3 & 1.9 & 2.7 \\
\hline $\mathbf{C a}$ & 32.7 & 47.4 & 100.2 & 5.1 \\
\hline $\mathbf{N a}$ & 15.7 & 1.5 & 2.7 & 14.2 \\
\hline $\mathbf{K}$ & 4.5 & 4.9 & 7.2 & 36.5 \\
\hline $\mathbf{T i}$ & 0.4 & 2.4 & 1.0 & 1.3 \\
\hline $\mathbf{P}$ & 14.0 & 19.4 & 4.3 & 0.9 \\
\hline LOI* $(\% \mathrm{w} / \mathrm{w})$ & 84.9 & 64.0 & 19.3 & 1.0 \\
\hline
\end{tabular}

* Loss on ignition

As expected in silicate minerals, $\mathrm{Si}$ content in gravel and sand was very high. The loss on ignition values observed in gravel $(4.3 \% \mathrm{w} / \mathrm{w})$ and sand $(0.9 \% \mathrm{w} / \mathrm{w})$ were also indicative of the low organic matter content in these samples compared to suspended solid and sludge $(84.9 \% \mathrm{w} / \mathrm{w}$ and $64.0 \% \mathrm{w} / \mathrm{w}$ respectively). Phosphorus contents in the filtration layers were determined as $4.32 \mathrm{~g} \mathrm{~kg}^{-1}$ for the gravels below the sludge layer in the first stage and $0.92 \mathrm{~g} \mathrm{~kg}^{-1}$ for the sand in the second stage. Two hypotheses may be proposed to explain the presence of phosphorus at significant concentrations within the filtration layers:

- The first hypothesis considers the migration of soluble forms of phosphorus through the filter media via convective transfer with the percolating flow of water, followed by their adsorption onto the surface of the particles of gravel and sand. Several studies have shown however that phosphorus sorption capacities of gravels and sands are low to very low (from 0.0258 to $0.0475 \mathrm{~g} \mathrm{P} \mathrm{kg}^{-1}$ gravels and from 0.117 to $1.0 \mathrm{~g} \mathrm{P} \mathrm{kg}^{-1}$ sands) (Mann and Bavor, 1993; Arias et al., 2001; Pant et al., 2001; Vohla et al., 2007). Preliminary studies performed in our laboratory on sand and crushed particles of gravels $(<1 \mathrm{~mm})$ showed that the phosphorus sorption capacities were much below $1 \mathrm{~g} / \mathrm{kg}$ and did not exceed $3 \mathrm{~g} \mathrm{P} \mathrm{kg}^{-1}$. Therefore, the phenomenon of migration and sorption of soluble forms of $\mathrm{P}$ may not explain the higher concentrations observed in the filtration layer of the first stage (4.32 $\mathrm{g} \mathrm{kg}^{-1}$ ), suggesting that some other phenomenon occurred.

- The second hypothesis is based on the migration of colloids or fine particles containing phosphorus under different possible forms. The particles of concern may be bacterial cell or clusters, or particles produced by the precipitation or sorption of phosphorus resulting from injection of $\mathrm{FeCl}_{3}$.

The results obtained in the present study showed that the second phenomenon (particulate migration) was predominant in the migration of phosphorus over small distances (i.e. not deeper than the first filter stage), whereas the first mechanism could well explain the migration of phosphorus over longer distances. In all cases however, phosphorus concentrations measured in the filter media (4.32 and $0.92 \mathrm{~g} \mathrm{~kg}^{-1}$ ) were very small as compared to the concentration in the sludge layer $\left(19.4 \mathrm{~g} \mathrm{~kg}^{-1}\right)$. These results showed that the 
major potential source of phosphorus release in the system was the sludge layer accumulated at the surface of the first pf-VFCW stage. Further investigations on these materials were thus necessary to better understand the mineralogical assemblage.

\section{$\underline{\text { Mineralogic analyses }}$}

XRD diffractograms are presented in Figure 3 and some identified mineral phases are listed in Table 2.

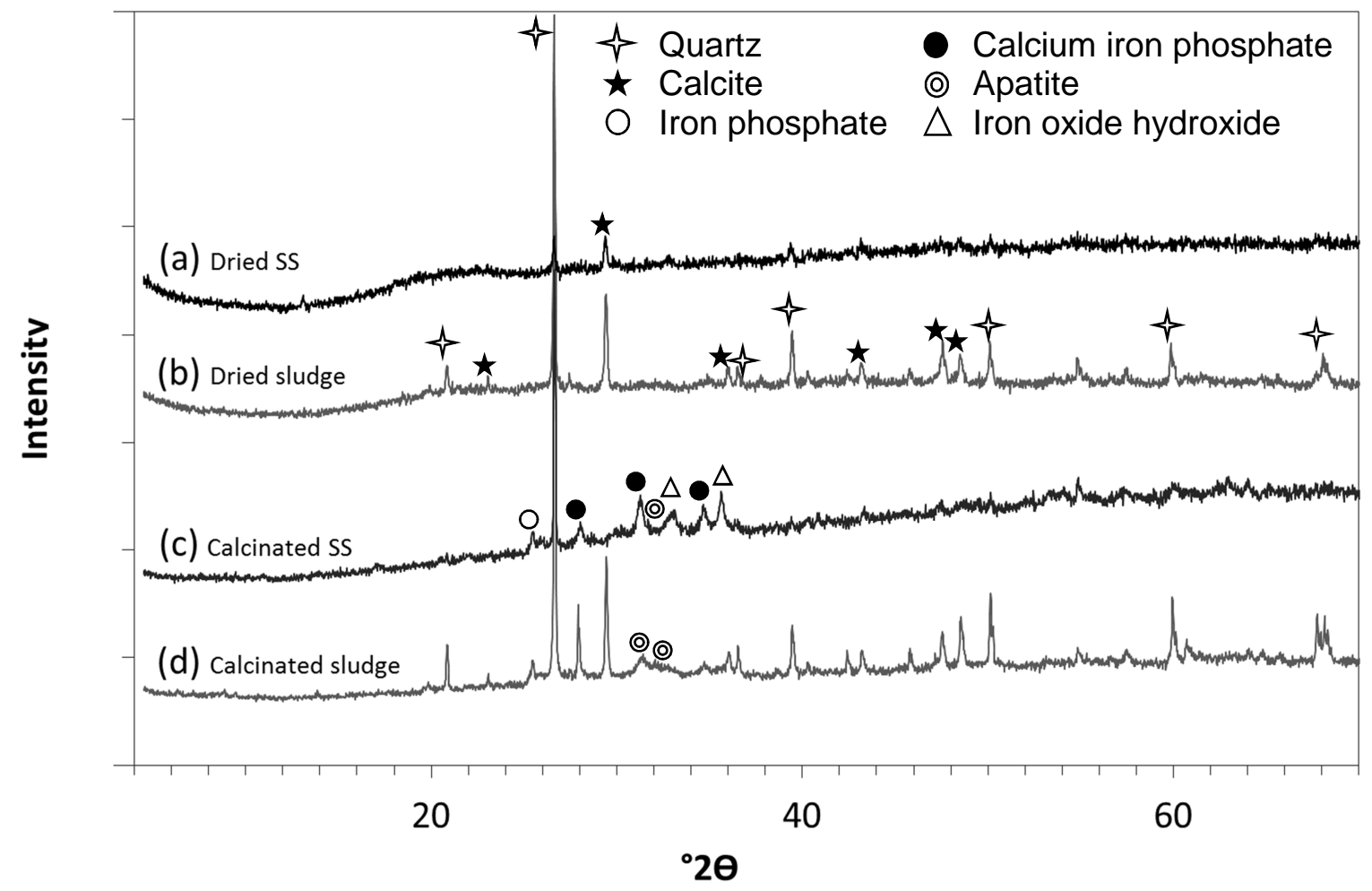

[Figure 3] XRD diffractograms of dried (a) suspended solid, (b) sludge and calcinated at $550^{\circ} \mathrm{C}(\mathrm{c})$ suspended solid, (d) sludge.

Quartz was clearly observed in each sample. The presence of calcite was largely more visible in sludge samples than in SS samples, probably due to the mineralization of the sludge with time at the top of the pf-VFCW stage. When the samples were analyzed without being pretreated by calcination, phase identification was very difficult because of the strong presence of organic matter and amorphous phases, especially in the suspended solid (SS) sample. When calcination was used as a pretreatment to remove organic matter, the observation of mineral phases was facilitated. As expected, iron phosphate was clearly identified. Phases were also observed in SS and sludge samples where phosphate was mainly associated with calcium, with low quantity of iron. Some substitutions of calcium with aluminium and magnesium could also occur. Calcium phosphate was also observed as apatite structure, mainly highlighted in calcinated sludge sample. The presence of iron oxide hydroxide in SS sample was also observed to a lower extent as suggested by Smith et al. (2008). 
[Table 2] Mineral phases identified by XRD in suspended solid (ss) and sludge.

\begin{tabular}{llcccc}
\hline \multirow{2}{*}{ Identified phase } & \multirow{2}{*}{ Chemical formula } & \multicolumn{4}{c}{ Presence inside sample } \\
\cline { 3 - 6 } & & $\mathrm{SS}$ & $\mathrm{S}$ Sludge & $\mathrm{C}-\mathrm{SS}$ & C-Sludge \\
\hline Quartz & $\mathrm{SiO}_{2}$ & $\mathrm{O}$ & $\mathrm{O}$ & $\mathrm{O}$ & $\mathrm{O}$ \\
Calcite & $\mathrm{CaCO}_{3}$ & - & - & - & $\mathrm{O}$ \\
Iron phosphate & $\mathrm{Fe}\left(\mathrm{PO}_{4}\right)$ & - & - & $\mathrm{O}$ & $\mathrm{O}$ \\
Ca-Fe phosphate & $\mathrm{Ca}_{19} \mathrm{Fe}_{2}\left(\mathrm{PO}_{4}\right)_{14}$ & - & - & $\mathrm{O}$ & $\mathrm{O}$ \\
Apatite & $\mathrm{Ca}_{10}\left(\mathrm{PO}_{4}\right)_{6}(\mathrm{OH})_{2}$ & - & - & $\mathrm{O}$ & - \\
Fe oxide hydroxide & $\mathrm{Fe}_{1.8} \mathrm{O}_{2.4}(\mathrm{OH})_{0.6}$ & - & & \\
* SS: Suspended Solid, C-: Calcinated & & &
\end{tabular}

Figure 4 shows FTIR spectra of dried and calcinated suspended solid and sludge samples. FTIR spectra of dried samples showed peaks for mineral and organic matter whereas those of calcinated samples exhibited only mineral part of the materials. The spectrum of dried suspended solid was very similar to those obtained by El Samrani et al. (2004) on freeze-dried coagulated species formed in the system ferric chloride/municipal sewage.

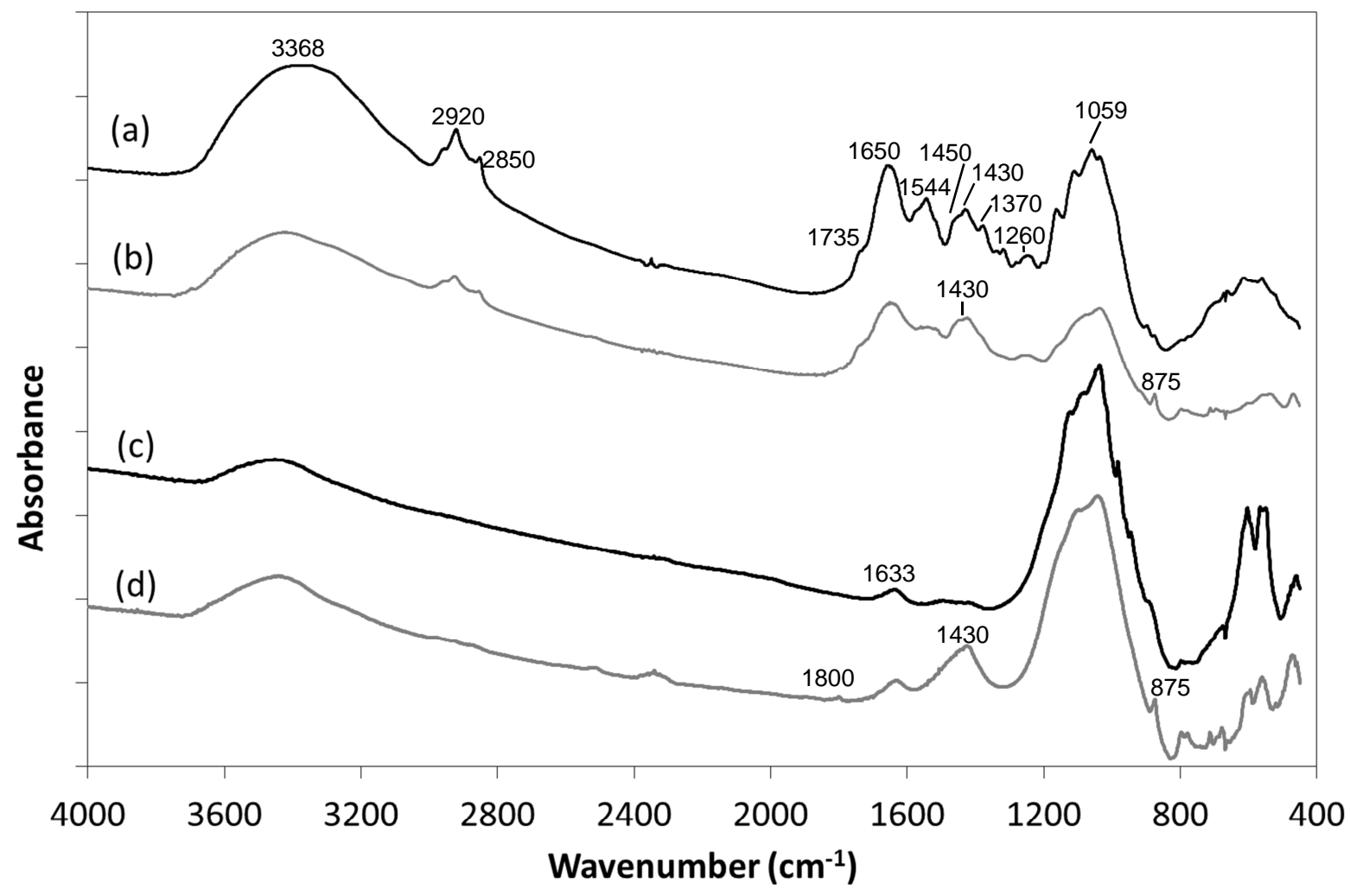

[Figure 4] FTIR spectra of (a) dried suspended solid, (b) dried sludge, (c) calcinated at $550^{\circ} \mathrm{C}$ suspended solid, (d) calcinated at $550^{\circ} \mathrm{C}$ sludge.

The FTIR spectra exhibited a broad intense band with a maximum around $3400 \mathrm{~cm}^{-1}$. This wide band is usually attributed to the stretching vibration of bonded and nonbonded hydroxyl groups (Haberhauer et al., 1998). The spectra of dried samples (Figure 4, a-b) showed several bands characteristics of the natural organic matter (NOM). The bands between 3000 and $2800 \mathrm{~cm}^{-1}$ were related to stretching vibrations of aliphatic (Smidt et al., 2005) methyl and methylene groups: asymmetric stretch at $2920 \mathrm{~cm}^{-1}$ and symmetric at $2850 \mathrm{~cm}^{-1}$ (Ellerbrock et al., 2005). The broad band at $1650 \mathrm{~cm}^{-1}$ could be assigned to $\mathrm{C}=\mathrm{C}$ bonds, $\mathrm{C}=\mathrm{O}$ and $\mathrm{OH}$ 
bending vibrations from water. Smidt et al. (2002) showed that these bands decrease during decomposition of the organic matter. The 2920,2850 and $1650 \mathrm{~cm}^{-1}$ bands decrease in sludge sample (Figure 4, a-b) clearly showed that composting process of biowaste is more advanced in sludge that in suspended solid.

For organic matter, most of the other bands occurred in the range $1800-1200 \mathrm{~cm}^{-1}$. The shoulder at $1735 \mathrm{~cm}^{-1}$ was attributed to carboxylic band. The band at $1544 \mathrm{~cm}^{-1}$ was assigned to N-H in plane (amide-II) (Smidt et al., 2002). This band decreased in sludge sample compared to suspended solid. Two bands appeared above 1450 and $1370 \mathrm{~cm}^{-1}$ which can be assigned to $\mathrm{C}-\mathrm{H}$ deformations of aliphatic groups (Parker, 1971). For organic part the broad band around $1430 \mathrm{~cm}^{-1}$ was attributed to the symmetric $\mathrm{C}-\mathrm{O}$ stretch from $\mathrm{COO}^{-}$or $\mathrm{OH}$ deformation from $\mathrm{COOH}$ (Parker, 1971). Moreover, the bands appearing below $1300 \mathrm{~cm}^{-1}$ (1280 and $1260 \mathrm{~cm}^{-1}$ ) could be attributed to aromatic ethers and phenols (Francioso et al., 1998). The broad band centered approximately at $1260 \mathrm{~cm}^{-1}$ was assigned to the C-O stretching of phenolic $\mathrm{OH}$ and/or arylmethylether and could be indicative of lignin backbone (Artz et al., 2008).

Other bands in this range $1800-1200 \mathrm{~cm}^{-1}$ could notably be attributed to $\mathrm{CH}$ and $\mathrm{NH}$ bending motions, aromatic stretch and carbon oxygen bond vibrations. The intensities of most of these bands decreased in sludge spectra compared to suspended solid spectra. This observation confirmed the mineralization process in the sludge and the transformation of the organic matter. Moreover after calcination process, all the bands assigned to organic matter were not visible anymore.

Thus the carbonation of sludge with time was also clearly highlighted in calcinated sludge sample with bands at 1427 and $875 \mathrm{~cm}^{-1}$ (Figure 4, d) characteristic of carbonates. However band at $875 \mathrm{~cm}^{-1}$ was already attributed to $\mathrm{P}-\mathrm{OH}$ in $\mathrm{H}_{2} \mathrm{PO}_{4}{ }^{-}$and $\mathrm{H}_{3} \mathrm{PO}_{4}$ (Tejedor-Tejedor and Anderson, 1990). The H-O-H bending band of water was observed at $1633 \mathrm{~cm}^{-1}$ in both calcinated samples. The broad band around $1050 \mathrm{~cm}^{-1}$ could be assigned to Si-O vibrations. This band, characteristic of mineral part of the sample, clearly increased after calcination of organic matter (Figure 3, c-d). Several bands below $800 \mathrm{~cm}^{-1}$ were indicative of inorganic minerals such as clay and quartz minerals. It is important to note that below $1100 \mathrm{~cm}-1$ the large variety of organic and mineral substances resulted in the existence of peaks that overlapped. FTIR vibrations of phosphate compounds were largely observed in the range 1000-1100 cm-1 (Arai and Sparks, 2001) but were hidden by the importance of Si-O vibrations at these wavelengths.

\section{Conclusions}

The results of this study firstly revealed the mineralization of the sludge accumulated at the surface of pf-VFCW. This was demonstrated by comparing the results of chemical analyses of the "suspended solids" (which are the source materials of the sludge) and the sludge taken at the surface of the first filter. It was also shown that phosphorus was principally concentrated in the sludge layer at the surface of the first stage.

Phosphorus contents observed in the gravels $(19.3 \% \mathrm{w} / \mathrm{w})$ and sand $(1.0 \% \mathrm{w} / \mathrm{w})$ highlighted that a partial migration of phosphorus did occur through the filtration layers. This result suggested that the mechanism of colloidal or particulate migration of phosphorus was predominant over small distances (i.e. not deeper than the first filter stage), whereas the 
mechanism of convective transfer of dissolved forms could explain the migration of phosphorus over longer distances.

XRD and FTIR analyses revealed the carbonation of the sludge, thereby confirming its mineralization. XRD allowed the identification of phosphorus forms mainly associated with iron as expected with iron chloride injection, but also largely with calcium. Further studies are underway to distinguish and quantify different forms of phosphorus in solid materials using sequential and/or selective extractions.

\section{Acknowledgements}

The authors would like to thank the SARM (Service of Analyses of Rocks and Minerals) for chemical elemental analyses, Ruben VERA from Henri Longchambon diffractometry centre and Tina LE BIHAN for their precious helping in XRD and FTIR analysis respectively. They are also grateful to SCIRPE and CIFRE for funding the research. The authors are grateful to the editor and the two anonymous referees for reviewing the manuscript and for their valuable comments on the paper.

\section{References}

Arias, C. A., Del Bubba, M. and Brix, H., 2001. Phosphorus removal by sands for use as media in subsurface flow constructed reed beds. Water Research 35(5): 1159-1168.

Arai, Y and Sparks, D. L., 2001. ATR-FTIR Spectroscopic Investigation on Phosphate Adsorption Mechanisms at the Ferrihydrite-Water Interface. Journal of Colloid and Interface Science. 241(2), 317-326.

Artz, R. R., Chapman, S. J., Robertson, A. J., Potts, J. M., Laggoun-Défarge, F., Gogo, S., Comont, L., Disnar, J.-R. and Francez, A.-J., 2008. FTIR spectroscopy can be used as a screening tool for organic matter quality in regenerating cutover peatlands. Soil Biology \& Biochemistry 40(2): 515-527.

Brix, H., Arias, C. A. and del Bubba, M., 2001. Media selection for sustainable phosphorus removal in subsurface flow constructed wetlands. Water Science and Technology 44(11-12): 47-54.

Caravelli, A. H., Contreras, E. M. and Zaritzky, N. E., 2010. Phosphorous removal in batch systems using ferric chloride in the presence of activated sludges. Journal of Hazardous Materials 177(1-3): 199-208.

De Gregorio, C., Caravelli, A. H. and Zaritzky, N. E., 2011. Application of biological indices and a mathematical model for the detection of metal coagulant overload in a laboratory scale activated sludge reactor with phosphate simultaneous precipitation. Chemical Engineering Journal 172(1): 52-60.

El Samrani, A.G., Lartiges, B.S., Montargès-Pelletier, E., Kazpard, V., Barrès, O. and Ghanbaja, J., 2004. Clarification of municipal sewage with ferric chloride: the nature of coagulant species. Water Research 38: 756-768.

El Samrani, A.G., Lartiges, B.S., Villiéras, F., 2008. Chemical coagulation of combined sewer overflow: Heavy metal removal and treatment optimization. Water research 42(4-5): 951-960.

Ellerbrock, R.H., Gerke, H.H., Bachmann J. and Goebel M.-O., 2005. Composition of organic matter fractions for explaining wettability of three forest soils. Soil Science Society of America Journal 69(1): 57-66. 
Francioso, O., Sanchez-Cortes, S., Tugnoli, V., Ciavatta, C. and Gessa, C., 1998. Characterization of Peat Fulvic Acid Fractions by Means of FT-IR, SERS, and 1H, 13C NMR Spectroscopy. Applied spectroscopy 52(2): 270-277.

Golterman, H. L., 2001. Phosphate release from anoxic sediments or 'What did Mortimer really write?'. Hydrobiologia 450(1): 99-106.

Haberhauer, G., Rafferty, B., Strebl, F. and Gerzabek, M.H., 1998. Comparison of the composition of forest soil litter derived from three different sites at various decompositional stages using FTIR spectroscopy. Geoderma 83(3-4): 331-342

Hammer, D. A., 1989. Constructed wetland for wastewater treatment : municipal, industrial, and agricultural, Lewis Publishers, Chelsea.

Kadlec, R., Knight, R., Vymazal, J., Brix, H., Cooper, P. and Haberl, R., 2000. Constructed Wetlands for Pollution Control. Processes, Performance, Design and Operation. IWA Scientific and Technical report No. 8, IWA Publishing, London.

Kadlec, R.H. and Wallace, S.D., 2009. Treatment Wetlands, second ed. Taylor and Francis Group, Boca Raton, USA.

Kim, B., Gautier, M., Molle, P. Michel, P., Prost-Boucle, S., Colombet D. and Gourdon R., 2012. Field study of wastewater treatment with partially flooded vertical-flow constructed wetlands using AZOE® process. $13^{\text {th }}$ Wetland Systems for Water Pollution Control. Perth, Australia.

Mann, R. A. and Bavor, H. J., 1993. Phosphorus Removal in Constructed Wetlands Using Gravel and Industrial Waste Substrata. Water Science and Technology 27(1): 107-113.

Michel, P., 2007. Procédé et installation de traitement d'effluents. EP 1857419 A1.

Michel, P., 2012. Procédé et installation de traitement d'effluents. PCT/EP2012/058119.

Molle, P., Liénard, A., Boutin, C., Merlin, G. and Iwema, A., 2005. How to treat raw sewage with constructed wetlands: an overview of the French systems. Water Science and Technology 51(9): 11-21.

Parker, F.S., 1971. Applications of Infrared Spectroscopy in Biochemistry. Biology and Medicine. Adam Hilger, London.

Pant, H. K., Reddy, K. R. and Lemon, E., 2001. Phosphorus retention capacity of root bed media of sub-surface flow constructed wetlands Ecological Engineering 17(4): 345355.

Smidt, E., Lechner, P., Schwanninger, M., Haberhauer, G. and Gerzabek, M.H., 2002. Characterization of waste organic matter by FT-IR spectroscopy: application in waste science. Applied Spectroscopy 56(9): 1170-1175.

Smidt, E., Eckhardt, K.U., Lechner, P., Schulten, H.R. and Leinweber P., 2005. Characterization of different decomposition stages of biowaste using FT-IR spectroscopy and pyrolysis-field ionization mass spectrometry. Biodegradation 16(1): 67-79.

Smith, S., Takacs, I., Murthy, S., Daigger, G. T. and Szabo, A., 2008. Phosphate Complexation Model and Its Implications for Chemical Phosphorus Removal. Water Environment Research 80(5): 428-438.

Szabó, A., Takács, I., Murthy, S., Daigger, G.T., Licskó, I. and Smith, S., 2008. Significance of design and operational variables in chemical phosphorus removal. Water Environment Research 80(5): 407-416.

Tejedor-Tejedor, I. and Anderson, M., 1990. Protonation of phosphate on the surface of goethite as studied by CIR-FTIR and electrophoretic mobility. Langmuir 6: 602-611.

Vohla, C., Alas, R., Nurk, K., Baatz, S. and Mander, U., 2007. Dynamics of phosphorus, nitrogen and carbon removal in a horizontal subsurface flow constructed wetland. Science of The Total Environment 380(1-3): 66-74. 
Vohla, C., Kõiv, M., Bavor, H. J., Chazarenc, F. and Mander, Ü., 2011. Filter materials for phosphorus removal from wastewater in treatment wetlands-A review. Ecological Engineering 37(1): 70-89. 